\title{
Whole foods and increased dietary fibre improve blood glucose control in diabetic children
}

\author{
A-L KINMONTH, R M ANGUS, P A JENKINS, M A SMITH, AND J D BAUM
}

Department of Paediatrics, John Radcliffe Hospital, Oxford

SUMMARY In prescribing a diabetic diet more attention has traditionally been paid to the amount of dietary carbohydrate than to its type or structure. We have compared the effect on blood glucose of substituting unrefined, whole foods for refined, processed foods in liberal carbohydrate diets (50-55\% of dietary energy) eaten by 10 diabetic children in a randomised crossover study. All measurements were made at home. The unrefined diet used whole foods (including dried beans) supplying $60 \mathrm{~g} /$ day of dietary fibre. The refined diet used processed foods supplying $20 \mathrm{~g} / \mathrm{day}$ of dietary fibre. Diets were isocaloric for carbohydrate, fat, and protein. Glycaemic control was assessed by daily urine analysis for glucose, home blood glucose measurements, glycosylated haemoglobin, and by a 24-hour profile of blood and urinary glucose carried out at home after 6 weeks on each diet. Glycaemic control was significantly better on the unrefined diet. On profile days mean blood glucose levels on the unrefined and refined diets respectively were: preprandial: 5.5 and $8.4 \mathrm{mmol} / \mathrm{l}$; postprandial 8.5 and $12.2 \mathrm{mmol} / \mathrm{l}$. The mean 24-hour urinary glucose excretion on the unrefined diet was $9.3 \mathrm{~g}$ and on the refined diet was $38.0 \mathrm{~g}$. Six months after the study the children were eating appreciably more dietary fibre than before (mean increase $13.6 \mathrm{~g} /$ day). Attention to food type and structure can improve blood glucose control in diabetic children and should provide an acceptable and more rational basis for dietary prescription than one based on carbohydrate quantity alone.

Traditional diabetic diets have paid more attention to the amount of dietary carbohydrate than to its structure or type. There is however a substantial amount of evidence to suggest that changing the physical form of the food in the diet, ${ }^{12}$ and increasing the amount of specific types of dietary fibre it contains $^{34}$ can appreciably affect the insulin or blood glucose response to test meals in healthy volunteers. Furthermore, such dietary changes can improve blood glucose control during experimental diets in diabetic patients. ${ }^{5-9}$

However such studies have all been on adults, and there are no reports of dietary studies on diabetic children using modern methods of assessing control. The measurements reported have generally been made during single day admissions to hospital ${ }^{8}$ or during short periods on metabolic wards ${ }^{679}$ and it is not clear to what extent such results can be applied to everyday life, ${ }^{10}$ particularly in children with their variable exercise patterns.

In addition, the adult studies have all been on maturity-onset diabetics ${ }^{79}$ or insulin-dependent dia- betics without $\beta$-cell reserve. ${ }^{8}$ Their relevance to diabetic children in whom residual $\beta$-cell function may facilitate diabetic control ${ }^{11}$ is therefore unknown.

In some studies the amount as well as the source of carbohydrate in the diet has been altered, so making changes in the proportions of other proximate constituents, particularly fat. ${ }^{7} 8$ Moreover the amounts of dietary fibre used have been large, up to five times that in the normal British diet, and such diets are likely to be unpalatable to children (as well as to adults). 8

It is particularly important to establish practical measures for improving glycaemic control in diabetic children, since children are put at special risk of microvascular complications in middle age by the early onset of the disease. ${ }^{12}$

We have therefore performed an extended domiciliary study to investigate the effect on blood glucose and the acceptability to families of substituting naturally available high-fibre whole foods for the traditional low-fibre foods in the diets of diabetic children. 


\section{Clinical methods}

Patients. The study was approved by the Oxford Ethics Committee, and 10 willing diabetic children were recruited with the consent of their families and general practitioners. Group meetings and food demonstrations were used to explain the project, and parents and children gave written consent.

There were 4 girls and 6 boys with a mean age of $14 \cdot 1$ (range $11 \cdot 3-17 \cdot 0$ ) years. The mean duration of diabetes was 4.7 years (range 9 months to 14 years). The mean height centile was the 50th (range 25-90), and the mean weight centile was the 70th (range 10-90). On average they were $5.5 \%$ overweight for height $^{13}$ (range -6 to $+24 \%$ ). Two children had not begun their growth spurt, 3 were approaching maximum height velocity, and 5 had passed peak height velocity.

They were managed on a once-daily injection of Monotard and Actrapid (Novo), and their mean total insulin dose was 41 units/day (range 16-72) or 0.8 units/kg body weight (range $0 \cdot 5-1 \cdot 2$ ).

Dietary management before the trial consisted of a low fibre, carbohydrate-restricted diet excluding sucrose-containing foods.

Before the trial the children's diabetic control had varied with a mean glycosylated haemoglobin level of $11 \cdot 4 \%$ (range $9 \cdot 1-16 \cdot 0)^{*}$.

Diets. Two experimental diets were compared which were identical except for the type and structure of the carbohydrate food.

\section{Refined diet}

The refined diet was based on the diet normally eaten by the diabetic children, except that liberal amounts of carbohydrate were used. Refined grains-such as white bread and cereals-supplied about two-thirds of the total carbohydrate, and the remaining one-third came from processed fruits and vegetables, milk and yoghurt. Sucrose-containing foods were excluded. The diet supplied $1 \mathrm{~g}$ of dietary fibre for every 100 calories, which is representative of the average British diet. ${ }^{14}$

\section{Unrefined diet}

The unrefined diet supplied about half its carbohydrate as whole grains (wholemeal bread and cereals) and about half from fresh fruit and vegetables including dried beans. This diet supplied $3 \mathrm{~g}$ of dietary fibre for every 100 calories.

On both diets $55 \%$ of energy was prescribed as carbohydrate, with a constant ratio of simple to complex sugars of $2: 3 ; 30 \%$ of energy was prescribed as fat with a ratio of saturated to total mono- and

*See section on laboratory methods. polyunsaturated fats of $1: 1 ; 15 \%$ of energy was prescribed as protein, and at least $40 \%$ of this was animal protein. One pint of milk was prescribed daily on each diet.

Diets were calculated individually for each child on the basis of his average caloric intake estimated from a 4-day weighed food intake carried out at home. Dietary intake was calculated using data from current British food tables. ${ }^{15}$ Recipe books and individual meal plans were devised for each diet, and families were taught how to use them at home by the research dietician (RMA). Most families had not cooked with dried legumes or wholemeal flour before and required advice on preparation.

Protocol. Each diet was eaten by all children in random order. Diet order was alternated so that the first child began with the unrefined and the second with the refined diet and so on, until 5 children had eaten both diets in each order. Each diet was eaten for 6 weeks while the child lived his normal life at home. Packed lunches were taken to school.

During each 6-week period 24-hour diet histories were taken to assess the degree of compliance. Children did not have to continue eating foods they disliked.

The dietician (RMA) and doctor (ALK) spoke to each family by telephone at least once a week to give encouragement and advice. Every fortnight the doctor visited each child's home to take blood for glycosylated haemoglobin level and to assess progress. Hypoglycaemic episodes were recorded at this visit. These were defined as mild (shaky feeling before meals), moderate (sweating, dizziness, or blurred vision responding to a biscuit or meal within 10 minutes), or severe (reduction in conscious level requiring the assistance of a second person). During each dietary period the concentration of urinary glucose was estimated by the children 3-times daily before main meals using the 2-drop Clinitest method $^{16}$ (Ames), and regular capillary blood glucose measurements were made each fortnight by the family using the Ames/Eyetone system.

During the first 2 weeks of the project the children were weaned on to the diets over 4-10 days and insulin and dietary distribution were altered to try to achieve negative glycosuria, preprandial capillary blood glucose levels of 3-7.5 mmol/1, and 1-hour postprandial levels of $10 \mathrm{mmol} / 1$ or less. On the second diet insulin dose was altered only in response to persistent glycosuria (all Clinitest results $>1 \%$ ) or hypoglycaemia (symptomatic, or preprandial or nocturnal capillary blood glucose $<2.5 \mathrm{mmol} / \mathrm{l}$ ).

During the final month of each diet, the control achieved under normal living conditions was assessed from the regular urinary glucose measurements and a 
series of capillary blood glucose measurements. Children were asked to record blood glucose levels before and one hour after main meals, before bed, and at 0300 hours on different days. On average, children performed two tests every other day throughout the final month on each diet. However each child performed a different number of tests, and the statistical analysis was based on a minimum series decided in advance. This consisted of tests bracketing the three main meals, each bracket being performed twice in the month.

After 6 weeks on each diet, control achieved was assessed under standard conditions at home during 24-hour 'profile days'. On these days unrefined or refined menus were prescribed for each child (Table 1) and care was taken to match the energy, carbohydrate, fat, and protein content meal for meal, especially during the morning (Table 2 ). Beans were eaten at breakfast and at the 1800-hour meal on the profile day of the unrefined diet. Exercise on profile days consisted of walks during the mornings and activities-such as shopping and walking, or playing table games-for the rest of the day. These activities were duplicated on the second profile day.

During the morning of the profile days the blood glucose and plasma c-peptide response to breakfast was measured using an indwelling venous cannula as previously described. ${ }^{17}$ Blood was sampled 11 times during the morning from 45 minutes before breakfast to 240 minutes afterwards when the cannula was removed (Fig. 1). Insulin was given 30 minutes before breakfast into a standard site in the thigh, and a snack was eaten at 150 minutes after breakfast.

During the second part of the profile children measured capillary blood glucose before and one hour after the beginning of the midday and the 1800-hour meal, at bedtime, at 0300 hours, and the next morning (Fig. 2). Throughout the 24 hours the urine volume passed at each voiding was measured by each child, and aliquots were collected for laboratory estimation of urinary glucose.

At the end of each 6-week period families recorded their reactions to the two diets on a questionnaire. When the trial ended families were encouraged to

Table 1 Example of menus eaten on profile days on the unrefined and refined diets: these menus were chosen by an 11-year-old boy. Energy $1800 \mathrm{kcals}, 55 \%$ as carbohydrate

\begin{tabular}{|c|c|c|c|c|}
\hline \multirow[t]{2}{*}{ Meal } & \multicolumn{2}{|c|}{ Unrefined diet } & \multicolumn{2}{|c|}{ Refined diet } \\
\hline & $\begin{array}{l}\text { Weight } \\
(g)\end{array}$ & Food & $\begin{array}{l}\text { Weight } \\
(g)\end{array}$ & Food \\
\hline Breakfast & $\begin{array}{r}60 \\
25 \\
210\end{array}$ & $\begin{array}{l}\text { Baked beans (home made) } \\
\text { Wholemeal toast } \\
\text { Milk }\end{array}$ & $\begin{array}{r}25 \\
210\end{array}$ & $\begin{array}{l}\text { Cornflakes } \\
\text { Milk }\end{array}$ \\
\hline Morning break & $\begin{array}{r}23 \\
170\end{array}$ & $\begin{array}{l}\text { Digestive biscuit } \\
\text { Unpeeled apple }\end{array}$ & $\begin{array}{r}30 \\
120\end{array}$ & $\begin{array}{l}\text { Semi-sweet biscuits } \\
\text { Peeled apple }\end{array}$ \\
\hline Midday meal & $\begin{array}{r}20 \\
10 \\
60 \\
45 \\
100 \\
10 \\
85 \\
120\end{array}$ & $\begin{array}{l}\text { Edam cheese } \\
\text { Lettuce } \\
\text { Tomato } \\
\text { Celery } \\
\text { Wholemeal bread } \\
\text { Butter } \\
\text { Unpeeled apple } \\
\text { Orange }\end{array}$ & $\begin{array}{r}20 \\
10 \\
60 \\
80 \\
12 \\
100 \\
55\end{array}$ & $\begin{array}{l}\text { Edam cheese } \\
\text { Lettuce } \\
\text { Tomato } \\
\text { White bread } \\
\text { Butter } \\
\text { Orange juice (unsweetened) } \\
\text { Fruit yoghurt }\end{array}$ \\
\hline Midafternoon break & $\begin{array}{l}75 \\
12 \\
85\end{array}$ & $\begin{array}{l}\text { Wholemeal bread } \\
\text { Butter } \\
\text { Bovril } \\
\text { Unpeeled apple }\end{array}$ & $\begin{array}{r}105 \\
30 \\
5 \\
15 \\
100\end{array}$ & $\begin{array}{l}\text { Milk } \\
\text { White bread } \\
\text { Butter } \\
\text { Bovril } \\
\text { Semi-sweet biscuit } \\
\text { Orange juice (unsweetened) }\end{array}$ \\
\hline Evening meal & $\begin{array}{r}55 \\
60 \\
80 \\
150 \\
5 \\
25 \\
160\end{array}$ & $\begin{array}{l}\text { Ham } \\
\text { Cooked (dried) beans } \\
\text { Cabbage } \\
\text { Boiled (unpeeled) potatoes } \\
\text { Butter } \\
\text { Wholemeal bread } \\
\text { Stewed blackberries }\end{array}$ & $\begin{array}{r}55 \\
60 \\
40 \\
100 \\
10 \\
40 \\
120 \\
120\end{array}$ & $\begin{array}{l}\text { Ham } \\
\text { Runner beans } \\
\text { Mushrooms } \\
\text { Boiled (peeled) potatoes } \\
\text { Butter } \\
\text { White bread } \\
\text { Orange } \\
\text { Stewed apple }\end{array}$ \\
\hline Bedtime snack & $\begin{array}{r}210 \\
15 \\
75 \\
7 \\
3\end{array}$ & $\begin{array}{l}\text { Milk } \\
\text { Weetabix } \\
\text { Banana } \\
\text { Digestive biscuit } \\
\text { Butter }\end{array}$ & $\begin{array}{r}210 \\
25 \\
15\end{array}$ & $\begin{array}{l}\text { Milk } \\
\text { Cornflakes } \\
\text { Semi-sweet biscuit }\end{array}$ \\
\hline
\end{tabular}


Table 2 Distribution of energy between protein, fat, carbohydrate, and quantity of dietary fibre at each meal on the unrefined and refined diets for the menus shown in Table 1

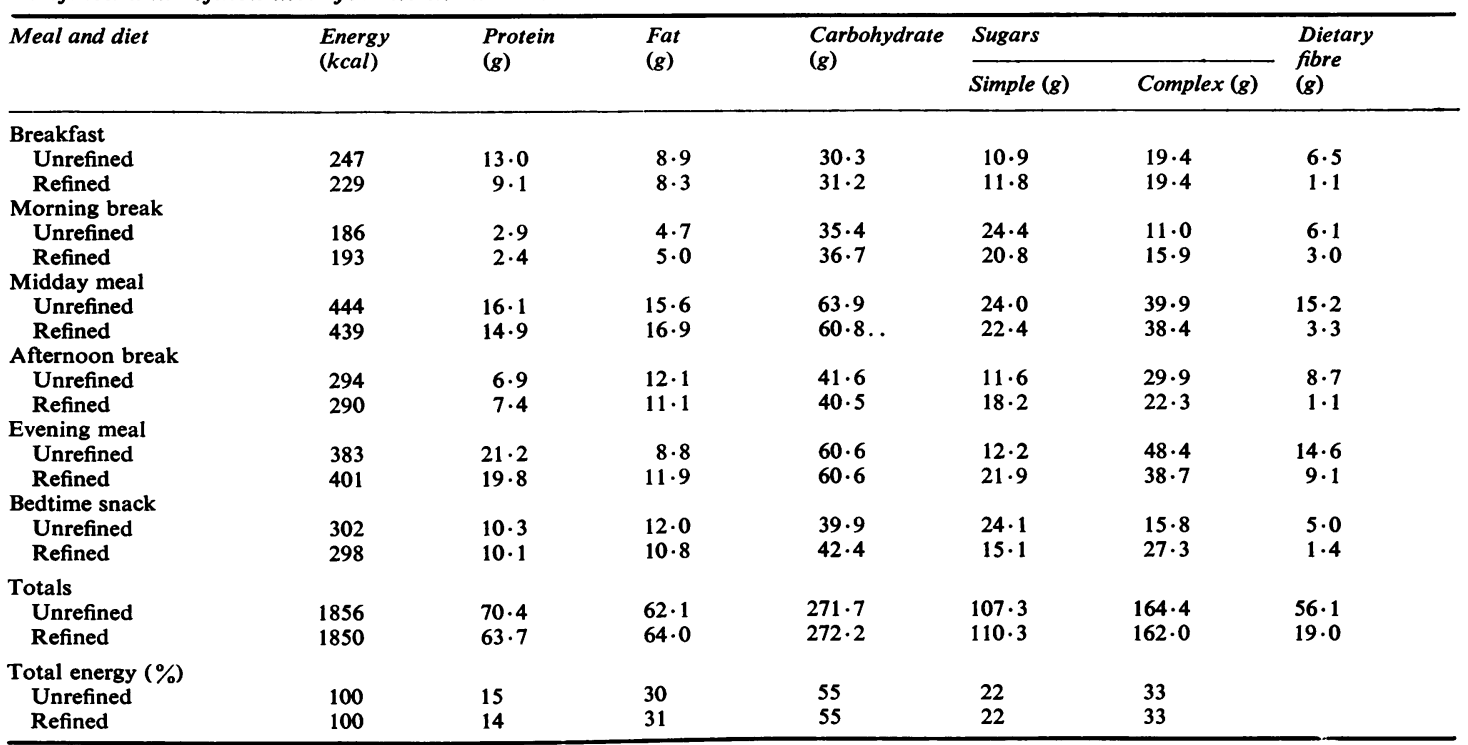

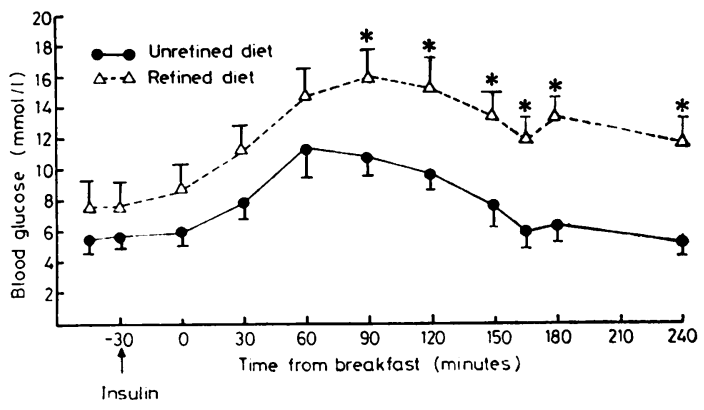

Fig. 1 Mean blood glucose levels in 10 diabetic children on profile mornings. Breakfast eaten at 0 minutes and snack at 150 minutes. Bars show $S E$.

*Significant difference between mean values at 90 minutes $P<0.05$, and at 120 minutes and later $P \gtrless 0 \cdot 01$.

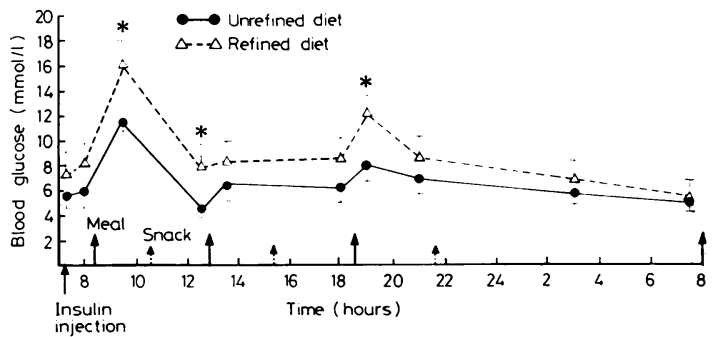

Fig. 2 Mean blood glucose levels in 10 diabetic children on profile days. Bars show SE.

*Significant differences between mean values at 0930 , 1230 hours, $P<0.05$; and at 1900 hours, $P<0.01$. continue to eat unrefined foods. Six months later the children's diets were assessed by 24-hour dietary recall and compared with their diets before the trial.

\section{Laboratory methods}

The fasting blood samples taken each fortnight were placed into EDTA tubes $(0 \cdot 5-1.0 \mathrm{ml})$ and stored at room temperature for 24 hours before estimation of total glycosylated haemoglobin using a small column ion exchange method. ${ }^{18}$ The normal range for glycosylated haemoglobin in our laboratory was 6.3 to $10.2 \%$ (mean $7.8 \%$ ), based on estimations from 38 normal children aged 4-18 years (mean age 13.6).

Each $4 \mathrm{ml}$ venous blood sample on profile days was handled as previously described. ${ }^{17}$ Blood glucose was estimated using a hexokinase method ${ }^{19}$ and c-peptide by charcoal separation radioimmunoassay $^{20}$ after polyethylene glycol extraction ${ }^{21}$ (antibody and tracer supplied by Novo, detection limit $0.02 \mathrm{nmol} / \mathrm{l})$. Urine glucose was estimated by a glucose oxidase method (YSI glucose analyser).

\section{Statistical analyses}

Differences between data pairs were tested for significance by Wilcoxon's rank sum test, except where shown in the tables. The $\mathrm{M}$-value ${ }^{22}$ was calculated using a reference value of $5.5 \mathrm{mmol} / 1$ which weights a blood glucose concentration of $3 \mathrm{mmol} / \mathrm{l}$ and $10 \mathrm{mmol} / \mathrm{l}$ as equally unsatisfactory. 


\section{Results}

Control on profile days. The mean blood glucose levels $( \pm$ SE) for the 10 children on both diets during the profile mornings are shown in Fig. 1. All blood glucose levels were lower on the unrefined diet. Mean prebreakfast levels were $5.6 \mathrm{mmol} / 1$ (SE 0.9) on the unrefined diet compared with $7.5 \mathrm{mmol} / \mathrm{l}$ (SE 1.7) on the refined one. Differences between blood glucose levels on the two diets increased during the morning to reach $5.2 \mathrm{mmol} / 1$ at 90 minutes and $6.5 \mathrm{mmol} / \mathrm{l}$ at 240 minutes after breakfast. Both the mean morning blood glucose level for each child and the area under the glucose curve were significantly smaller on the unrefined diet (Table 3).

The mean blood glucose levels for the rest of the profile day are shown in Fig. 2. This is made up from the morning profile and the capillary blood glucose levels from lunchtime. Blood glucose levels continued lower on the unrefined diet throughout the day and the difference between the unrefined and the refined diet reached statistical significance one hour after tea when the mean blood glucose level was $4.1 \mathrm{mmol} / \mathrm{l}$ lower on the unrefined diet.

Further analyses of the blood glucose levels during the day are shown in Table 3. Mean preprandial blood glucose levels (mean of values before breakfast, midday, and 1800-hour meal), and mean postprandial levels (mean of values one hour after 3 main meals) were significantly lower on the unrefined diet. The mean postprandial increment (mean of one hour increment across 3 main meals) was similar on both diets, but the mean 1-hour increment after breakfast was significantly lower on the unrefined $(5 \mathrm{mmol} / \mathrm{l})$ than the refined diet (7.8 mmol/l), $\mathrm{P}<0.05$.

The mean 24-hour blood glucose levels, the mean 24-hour urinary glucose loss, and the M-value for each child were all significantly lower on the unrefined diet.

\section{C-peptide results}

Five children were classified as c-peptide producers on the basis of a 90 -minute postbreakfast increment in c-peptide greater than $0.03 \mathrm{nmol} / \mathrm{l}$. Their mean c-peptide increment was $0.25 \mathrm{nmol} / 1$ (range 0.04-0.64).

Control over the 6 weeks on each diet. The total mean capillary blood glucose levels taken at all sampling times during the final month of both diets are shown in Fig. 3. All blood glucose levels were lower on the unrefined diet. Analysis of the blood glucose pairs bracketing meals showed that the mean preprandial blood glucose levels and the mean postprandial blood glucose levels were significantly lower on the unrefined diet (Table 4). The 1-hour postprandial increments were similar on both diets.

Table 3 Measurement of blood glucose control on profile days on each diet

\begin{tabular}{|c|c|c|c|}
\hline & Unrefined & Refined & $P$ value \\
\hline \multicolumn{4}{|c|}{ Morning blood glucose (mmol/1) } \\
\hline Mean and range & $7 \cdot 4(4 \cdot 4-13 \cdot 0)$ & $11 \cdot 9 \quad(2 \cdot 5-16 \cdot 8)$ & $<0.01$ \\
\hline SE & 0.8 & $1 \cdot 4$ & \\
\hline \multicolumn{4}{|c|}{ Area under morning curve $U / R \%$ : } \\
\hline Mean and range & $62.0 \quad(20-170)$ & $100 \cdot 0$ & $<0.01$ \\
\hline SE & $14 \cdot 0$ & & \\
\hline \multicolumn{4}{|c|}{ Preprandial blood glucose* $(\mathrm{mmol} / \mathrm{l})(\mathrm{n}=30)$} \\
\hline SE & $0 \cdot 3$ & $0 \cdot 3$ & \\
\hline \multicolumn{4}{|c|}{ Postprandial blood glucose $\dagger(\mathrm{mmol} / \mathrm{l})(\mathrm{n}=30)$} \\
\hline Mean & $8 \cdot 5$ & $12 \cdot 2$ & $<0.001 \S$ \\
\hline SE & 0.3 & $\mathbf{0 \cdot 3}$ & \\
\hline \multicolumn{4}{|c|}{ Postprandial blood glucose $\ddagger$ increment $(\mathrm{mmol} / \mathrm{l})(\mathrm{n}=30)$} \\
\hline Mean & $3 \cdot 0$ & $3 \cdot 8$ & NS § \\
\hline SE & 0.5 & 0.5 & \\
\hline \multicolumn{4}{|c|}{ 24-hour blood glucose ( $\mathrm{mmol} / \mathrm{l})$} \\
\hline Mean and range & $6 \cdot 9 \quad(3 \cdot 7-8 \cdot 8)$ & $9 \cdot 0 \quad(3 \cdot 0-16 \cdot 3)$ & $<0.01$ \\
\hline 24-hour urine gluco & & & \\
\hline Mean and range & $9 \cdot 3 \quad(0 \cdot 3-28 \cdot 8)$ & $38 \cdot 0 \quad(0 \cdot 3-152 \cdot 0)$ & $<0.01$ \\
\hline SE & $1 \cdot 2$ & $14 \cdot 7$ & \\
\hline \multicolumn{4}{|l|}{ M-value } \\
\hline Mean and range & $28 \quad(14-56)$ & $55 \quad(24-117)$ & $<0.01$ \\
\hline SE & 5 & 8 & \\
\hline
\end{tabular}

Conversion: SI to traditional units-glucose: $1 \mathrm{mmol} / 1 \approx 18 \mathrm{mg} / 100 \mathrm{ml}$.

* Mean of values before breakfast, midday, and the 1800 -hour meals.

+Mean of values 1 hour after 3 main meals.

¥Mean of one hour increment across 3 main meals.

§Analysis of variance.23

$\mathbf{U}=$ unrefined, $\mathbf{R}=$ refined. 


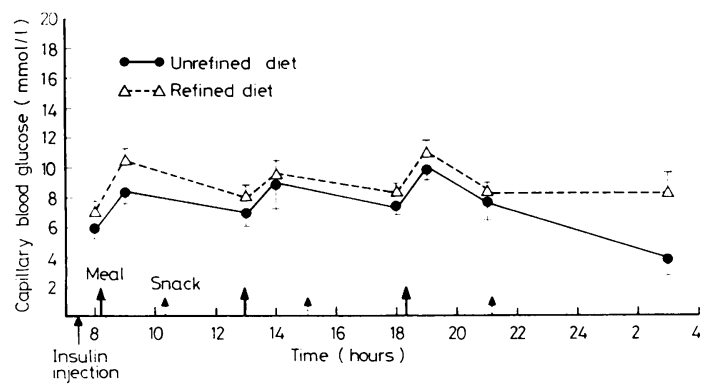

Fig. 3 Mean blood glucose levels in 10 diabetic children for all sampling times over final month of the unrefined $(n=353)$ and refined $(n=343)$ diets. The 0300-hour points relate to 5 children only.

Mean at each sampling time: unrefined diet 44 (SD 28); refined diet 43 (SD 25).

The proportion of preprandial urinary glucose tests that were negative during the final month of each diet is shown in Table 4. Significantly more tests were negative on the unrefined diet.

The changes in glycosylated haemoglobin during each period of 6 weeks is shown in Table 4. Glycosylated haemoglobin levels tended to fall during the unrefined diet and rise during the refined diet, but these differences were not statistically significant.

\section{Hypoglycaemia}

A mean of 5 hypoglycaemic episodes per child (range 0-12) were reported on the unrefined diet and a mean of 3 (range $0-8$ ) on the refined diet. The difference was not statistically significant. On both diets half the episodes were rated as mild and half as moderate in severity. One severe episode occurred on each diet. On the refined diet this followed a missed snack and unexpected exercise, and on the refined diet it occurred before the midday meal.
Insulin dose

The mean daily insulin dose on the unrefined diet was 39 units (SE 6) and on the refined diet 42 units (SE 6). Four children did not alter their dose between diets. Changes in dose of more than 2 units were confined to 3 of the c-peptide producers who required 6,8 , and 12 units less insulin on the unrefined diet. Their mean daily insulin dose on the unrefined diet was 25 units (SE 2), and on the refined diet 34 units (SE 3).

\section{Growth}

The 10 children grew by a mean of $0.8 \mathrm{~cm}$ (SE 0.3 ) during the 3-month trial and showed a mean weight increase of $0.4 \mathrm{~kg}$ (SE 0.32). Mean weight increased during both 6-week periods: by $0.1 \mathrm{~kg}$ (SE 0.5 ) on the unrefined and by $0.3 \mathrm{~kg}$ (SE 0.6 ) on the refined diet.

\section{Diet acceptability}

Mild flatulence was experienced by all children during the first week of the unrefined diet, and 3 children experienced transient loose stools during this week. Four children preferred the unrefined diet, 4 preferred the refined diet, and 2 liked neither. After the first week, 8 of the children could eat the amount of food prescribed on the unrefined diet, but 2 sometimes left some green vegetables. All members of 7 families ate the trial foods with their children, but 3 fathers did not like beans.

Most children found the restricted amounts of meat and cheese on the diets unacceptable for longer than 3 months, and after the trial the proportion of energy eaten as carbohydrate was reduced slightly to allow more animal protein to be eaten.

The mean dietary intakes of the 10 children 6 months after the trial are compared with their pretrial diets in Table 5. The children had significantly

Table 4 Measurements of blood glucose control during 6 weeks of each diet

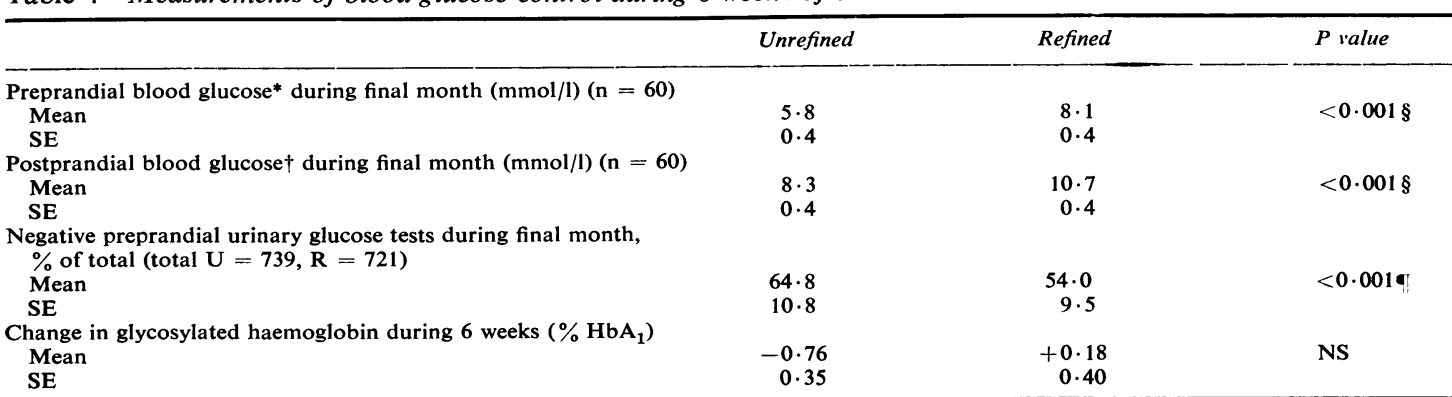

* Mean of values before breakfast, midday, and the 1800 -hour meals.

+ Mean of values 1 hour after 3 main meals.

$\S$ Analysis of variance.

Allowing for differences between children.

$\mathbf{U}=$ unrefined, $\mathbf{R}=$ refined 
Table 5 Effect of diet on proportions of protein, fat, carbohydrate, and dietary fibre eaten by participants

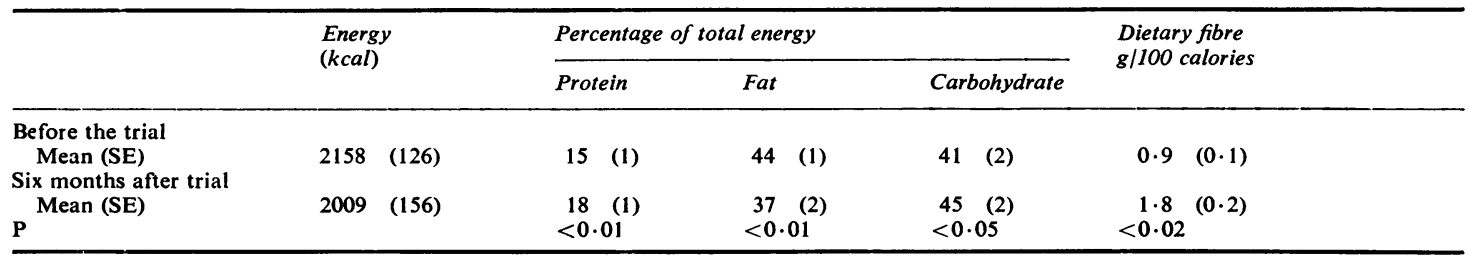

increased the proportion of dietary fibre, carbohydrate, and protein in their diets and had reduced the amount of fat.

\section{Discussion}

Our results show that attention to the type and structure of carbohydrate in the diet can appreciably improve the glycaemic control of diabetic children under normal living conditions.

Glycaemic control measured during 24 hours at home was significantly improved after eating a whole-food high-fibre diet for 6 weeks. Moreover, similar results were found on analysis of the blood glucose measurements made during the final month of each dietary period. These measurements were made on normal school days or at weekends, and suggest that incorporation of high-fibre whole foods in the diet makes a practical contribution to improving the glycaemic control of diabetic children.

The blood glucose results are supported by the urinary glucose results taken both on profile days and under normal living conditions. Significant changes in glycosylated haemoglobin were not seen however, perhaps because 4-6 weeks of improved control was too short a time interval.

'Compliance' may have been best on profile days, resulting in greater measured differences in blood glucose, but 'practical compliance' on other days was sufficient to result in significantly lower blood glucose levels throughout the final month of the unrefined diet. At the end of the trial all children elected to reduce slightly the proportion of dietary energy eaten as carbohydrate mainly in order to eat more meat. However, 6 months later they were still eating significantly more carbohydrate and protein and less fat than before the trial and had almost doubled their dietary fibre intake. Whether this dietary change is sufficient to make a practical contribution to glycaemic control remains to be established.

Our hypothesis was that the use of whole foods high in dietary fibre would retard carbohydrate absorption, and so match more closely the absorption of the injected insulin than could the traditional diet based on refined carbohydrate. This should have produced a flattening of the blood glucose profile during the day. This was not observed. Preprandial as well as postprandial blood glucose levels were reduced on the unrefined diet and the postprandial increment was similar on both diets except after breakfast.

These results suggest that reduction in the absorption rate of carbohydrate cannot be the only mechanism for the improved blood glucose control seen on the unrefined diet.

Similar results have also been reported among insulin-dependent adults fed a high-fibre diet. ${ }^{8}$ In the adult trial substantially higher amounts of dietary fibre were used and the proportions of carbohydrate and fat and the source of carbohydrate, fat, and protein foods in the diet were altered. Our results suggest that the general downward shift in blood glucose baseline can be achieved by altering the structure and type of carbohydrate alone, and by increasing the dietary fibre 2- or 3-fold, rather than 5 -fold as in the adult study.

In our study a reduction in insulin dosage of up to 12 units was required in 3 of the 5 children with residual $\beta$-cell activity to prevent hypoglycaemia on the unrefined diet. Reduction in insulin dosage in adult diabetics on high-fibre diets has been previously reported when the daily insulin dose was smaller than 30 units, but not when its was greater. ${ }^{7}$ This suggests that the improvement in blood glucose control associated with high-fibre whole food diets may be augmented by a recovery in $\beta$-cell function in patients with $\beta$-cell reserve.

There is no evidence that significant malabsorption occurred during the unrefined diet, since children continued to grow in height and weight throughout the trial and their mean weight gain at the end of each dietary period was very similar.

These results indicate that rational and acceptable dietary prescription can contribute to improvement of blood glucose control in diabetic children managed on a standard insulin regimen. They strongly suggest that the current system of carbohydrate exchanges based only on absolute carbohydrate content of foods with avoidance of sugar is inadequate. Since the physical architecture of the whole meal is likely to affect the glycaemic response 
on any diet, perhaps more emphasis in dietary prescription should be on the choice of carbohydrate food types, rather than simply on weighing out exchanges which may have little physiological meaning.

We thank Mr A Scott for help with statistics and Dr K McPherson for help with design.

A L K was supported by Novo Laboratories and R M A by a locally organised research grant.

\section{References}

1 Haber G B, Heaton K W, Murphy D, Burroughs L F. Depletion and disruption of dietary fibre. Lancet 1977; ii: $679-82$.

2 Coulston A, Greenfield M, Kraemer F, Tobey T, Reaven G. Effect of source of dietary carbohydrate on plasma glucose and insulin responses to test meals in normal subjects. Am J Clin Nutr 1980; 33: 1279-82.

3 Jenkins D J A, Wolever T M S, Leeds A R, et al. Dietary fibre, fibre analogues, and glucose tolerance: importance of viscosity. Br Med J 1978; i: 1392-4.

4 Jenkins D J A, Wolever T M S, Taylor R H, Barker H M, Fielden H. Exceptionally low blood glucose response to dried beans: comparison with other carbohydrate foods. Br Med J 1980; 281 : 578-80.

5 Goulder T J, Alberti K G M M. Dietary fibre and diabetes. Diabetologia 1978; 15: 285-7.

6 Miranda P M, Horwitz D L. High fibre diets in the treatment of diabetes mellitus. Ann Intern Med 1978; 88: 482-6.

7 Kiehm T G, Anderson J W, Ward K. Beneficial effects of a high carbohydrate, high fibre diet on hyperglycemic diabetic men. Am J Clin Nutr 1976; 29 : 895-9.

${ }^{8}$ Simpson H C R, Lousley S, Geekie M, et al. A high carbohydrate leguminous fibre diet improves all aspects of diabetic control. Lancet 1981 ; i: 1-5.

9 Rivellese A, Giacco A, Genovese S, et al. Effect of dietary fibre on glucose control and serum lipoproteins in diabetic patients. Lancet 1980; ii: 447-9.

10 Anonymous. High fibre diets and diabetes. Lancet 1981; i: $423-4$.

11 Grajwer L A, Pildes R S, Horwitz D L, Rubenstein A H.
Control of juvenile diabetes mellitus and its relationship to endogenous insulin secretion as measured by $\mathrm{C}$-peptide immunoreactivity. J Pediatr 1977; 90: 42-8.

12 Deckert T, Poulsen J, Larsen M. Prognosis of diabetics with diabetes onset before the age of 31 . Survival, causes of death, and complications. Diabetologia 1978; 14: 363-70.

13 Tanner J M, Whitehouse R H. Height and weight standard charts. 1975. Obtainable from Creaseys of Hertford Limited, Castlemead, Hertford SG14 1LH.

14 Bingham S, Cummings J H, McNeil N I. Intakes and sources of dietary fiber in the British population. Am J Clin Nutr 1979; 32: 1313-9.

15 Paul A A, Southgate D A T. McCance and Widdowson's The composition of foods, fourth edition. London: HMSO, 1978.

16 Belmonte M M, Sarkozy E, Harpur E R. Urine sugar determination by the two drop Clinitest method. Diabetes 1967; 16: 557-9.

17 Kinmonth A L, Baum J D. Timing of prebreakfast insulin injection and postprandial metabolic control in diabetic children. Br Med J 1980; 280: 604-6.

18 Welch S G, Boucher B J. A rapid micro-scale method for the measurement of haemoglobin $A_{1}(a+b+c)$. Diabetologia 1978; 14: 209-11.

19 Bergmeyer H U, Bernt E, Schmidt F, Stork H. D-glucose; determination with hexokinase and glucose 6-phosphate dehydrogenase. In: Bergmeyer $\mathrm{H}$ U, ed. Methods of enzymatic analysis. Vol. 3. New York: Academic Press, 1974: 1196-201.

20 Albano J D M, Ekins R P, Maritz G, Turner R C. A sensitive, precise radioimmunoassay of serum insulin relying on charcoal separation of bound and free hormone moieties. Acta Endocrinol (Kbh) 1972; 70: 487-509.

21 Kuzuya H, Blix P M, Horwitz D L, Steiner D F, Rubenstein A H. Determination of free and total insulin and C-peptide in insulin-treated diabetics. Diabetes 1977; 26: 22-9.

22 Schlichtkrull J, Munck O, Jersild M. The M-value, an index of blood-sugar control in diabetics. Acta Med Scand 1965; 177: 95-102.

23 Snedecor G W, Cochran W G. Statistical methods, sixth edition. Ames: Iowa State University Press, 1967: 339-69.

Correspondence to Dr A-L Kinmonth, Department of Paediatrics, John Radcliffe Hospital, Headington, Oxford OX3 9DU.

Received 21 April 1981 